\title{
Evaluation of Serum Cholinesterase Level as A diagnostic Marker in Chronic Liver Disease
}

\author{
Zayed Said Youssef Hassan*, Ahmed Mohammed Abdel Rahman Tahoun *, \\ Magdy Abdel Kareim Eldahshan ** and Ahmed Abdul-Hameid Abo-Zied* \\ Departments of Clinical Pathology* and Internal Medicine**, Al-Azhar Faculty of Medicine \\ E-mail: drzayedsaid@gmail.com
}

\begin{abstract}
Background: Liver is the main source of Butyrylcholinesterase (serum cholinesterase). It is a non-specific cholinesterase that is reduced in patients with advanced liver diseases. Measurement of serum Butyrylcholinesterase activity serves as a sensitive indicator of synthetic capacity of the liver.

Objective: To evaluate serum cholinesterase levels in chronic liver disease patients.

Patients and methods: In this study serum cholinesterase level was evaluated in chronic liver disease patients by a colorimetric kinetic assay method. Thirty cirrhotic subjects and thirty non-cirrhotic hepatic disease subjects were compared to 20 normal individuals. This study was done at Al-Azhar University Hospitals in the period between June 2018 and August 2020.

Results: A significant decrease in serum Cholinestrease level was observed in all patients of chronic liver disease as compared to control group.

Conclusion: Serum cholinesterase is a better diagnostic and prognostic marker than the conventional liver function test that are raised in other liver disease also.
\end{abstract}

Keywords: Serum cholinesterase, Albumin, Viral hepatitis, Liver cirrhosis.

\section{INTRODUCTION}

Liver disorders are the major leading cause of morbidity and mortality worldwide. Biochemical tests for the assessment of liver function (commonly referred to as liver function tests) includes measurement of serum total bilirubin, serum aspartate and alanine transaminases serum alkaline phosphatase, serum protein and albumin (Kumar and Keerthana, 2016).

Liver function tests are raised in non-liver diseases, e.g. transaminase levels in heart diseases, alkaline phosphatase levels in bone diseases etc. So, there is a need for a test which should be more specific, and sensitive for diagnosis of liver disease ( Chowdhry and Kaushik, 2017).
Cholinesterase is a family of enzymes that catalyze the hydrolysis of the neurotransmitter acetylcholine into choline and acetic acid, an essential process for the restoration of the cholinergic neurotransmission (Gülçin et al., 2016).

There are two types of cholinesterases, acetylcholinesterase (AChE) or erythrocyte cholinesterase, which is most concentrated in the central nervous system, striated muscle and erythrocyte membrane, and butyrylcholinesterase (BChE) or plasma cholinesterase, which is most abundant in plasma (Fonseca et al., 2020).

Cholinestrase has a serum half-life between 8 and 12 days(Amin et al., 2017).

Cholinesterase is synthesized mainly in hepatocytes and released into the blood. Cholinesterase activity is reduced in liver 
dysfunction due to reduced synthesis. The predominant hepatic source of serum cholinesterase, the marked decrease in its synthesis with hepatocyte dysfunction and restoration of synthesis with hepatocyte recovery suggests that serum cholinesterase activity might be a more specific indicator of liver dysfunction than the traditional liver function test (Roshankumar et al., 2019).

This study was performed to evaluate serum cholinesterase levels in chronic liver disease patients.

\section{SUBJECTS AND METHODS}

This study was done at Al-Azhar University Hospitals during the period between June 2018 and August 2020 on a total of 80 individuals (age and sex matched). Those individuals were divided into 2 groups: group1 (60 patients) and group 2 (20 control). The patients group was subdivided into two equal subgroups: Group 1(A) and Group 1(B) hepatic disease subjects. Control group were apparently healthy individuals.

Inclusion criteria: Patients presented with cirrhotic liver disease and non-cirrhotic hepatic disease aged between 40-65 years.

Exclusion criteria: Patients with congenital liver disorder, chronic malnutrition, organophosphorus poisoning, muscular dystrophy and pregnancy.

\section{Methods:}

I. Full history taking and clinical examination.

II. Sample Collection: Ten ml venous blood was withdrawn from all participants of the study (both patients and controls) ; $2 \mathrm{ml}$ on EDTA for routine CBC which was done using Sysmex Kx-21 automated cell counter, $2 \mathrm{ml}$ on $\mathrm{Na}$ citrate for Prothrombin time and the remaining amount in plain tube was left for clotting, and then centrifuged. Separated serum was divided in 2 aliquots, one for routine biochemical tests performed by an enzymatic colorimetric reaction using a Modular $\mathrm{P}$ analyzer (Roche Diagnostics) while the other aliquot was stored deeply frozen at $-20^{\circ} \mathrm{C}$ for estimation of serum cholinesterase.

Serum Cholinesterase was done using a Biolis 50i Superior analyzer by a colorimetric kinetic assay method using a commercially available kit supplied by BEN - BIOCHEMICAL ENTERPRISE, Milano, Italy.

\section{Statistical analysis:}

Data were analyzed using Statistical Package for the Social Sciences (SPSS) version 2, IBM Corp. U.S.A. Quantitative data were expressed as mean \pm standard deviation (SD). Qualitative data were expressed as frequency and percentage. P-value $\leq$ 0.05 was considered significant.

For all analyses, Chi-squared $\left(\mathrm{X}^{2}\right)$ test, Fisher's exact test, one way ANOVA test and Kruskal Wallis test were used.

\section{RESULTS}

Our study included a total of 80 individuals. 60 patients recruited to Al-Azhar university hospitals and 20 apparently healthy individuals.

Table (1) showed the demographic characteristics of study population in control and Chronic Liver Disease patients:

- Statistically significant difference (p-value $<\mathbf{0 . 0 5}$ ) between studied groups as regard ALP.

- Statistical significant difference (p-value < 0.001) between studied groups as regard ALT, AST, Albmin, Bilirubin ( $\mathrm{T} \& \mathrm{C}$ ), PT \& INR.

- $\quad$ Statistical significant difference (p-value < 0.001) between studied groups as regard TLC, PLTs \& Hb.

- No statistical significant difference (p-value $>\mathbf{0 . 0 5}$ ) between studied groups as regard $\mathrm{HBs}$ Ag.

- Statistically significant difference (p-value $<\mathbf{0 . 0 5}$ ) between studied groups as regard $\mathrm{HCV}$ Ab.

- Statistically significant difference (p-value $<\mathbf{0 . 0 5}$ ) between studied groups as regard AFP.

- Highly statistical significant difference (pvalue $<0.001$ ) between studied groups as regard Cholinesterase. 
Table (1): Demographic and laboratory data of all studied groups.

\begin{tabular}{|c|c|c|c|c|c|c|c|c|}
\hline \multicolumn{2}{|c|}{$\begin{array}{l}\text { Groups } \\
\text { Parameters }\end{array}$} & \multicolumn{2}{|c|}{$\begin{array}{c}\text { Group IA } \\
(n=30)\end{array}$} & \multicolumn{2}{|c|}{$\begin{array}{c}\text { Group IB } \\
(n=30)\end{array}$} & \multicolumn{2}{|c|}{$\begin{array}{l}\text { Control } \\
(\mathbf{n}=\mathbf{2 0})\end{array}$} & \multirow{3}{*}{$\begin{array}{c}\text { P-value } \\
0.251\end{array}$} \\
\hline \multirow{2}{*}{ Sex } & Male & 18 & $60 \%$ & 13 & $43.3 \%$ & & $60 \%$ & \\
\hline & Female & 12 & $40 \%$ & 17 & $56.7 \%$ & 18 & $40 \%$ & \\
\hline Age (Years) & Mean \pm SD & 56.7 & \pm 5.7 & 53.9 & \pm 4.4 & 55.1 & \pm 4.2 & 0.091 \\
\hline $\operatorname{ALT}(\mathbf{U} / \mathbf{L})$ & Mean \pm SD & 46.1 & \pm 5.6 & 49.8 & \pm 6.1 & 23.7 & \pm 5.3 & $<0.001$ \\
\hline $\operatorname{AST}(\mathbf{U} / \mathbf{L}))$ & Mean \pm SD & 55.6 & \pm 11.3 & 57.9 & \pm 8.7 & 28.9 & \pm 5.0 & $<0.001$ \\
\hline ALB (g\dl) & Mean \pm SD & 2.9 & \pm 0.5 & 3.6 & \pm 0.3 & 4.3 & \pm 0.5 & $<0.001$ \\
\hline $\operatorname{ALP}(\mathbf{U} / \mathbf{L})$ & Median - IQR & \multicolumn{2}{|c|}{$\begin{array}{c}215.4(158.8- \\
278.8)\end{array}$} & \multicolumn{2}{|c|}{$163.3(135-194)$} & \multicolumn{2}{|c|}{$\begin{array}{c}184.7(145.8- \\
220.5)\end{array}$} & 0.008 \\
\hline T Bil. (mg/dL) & Median - IQR & \multicolumn{2}{|c|}{$2.11(1.47-2.4)$} & \multicolumn{2}{|c|}{$0.78(0.63-0.9)$} & \multicolumn{2}{|c|}{$0.73(0.61-0.87)$} & $<0.001$ \\
\hline $\begin{array}{c}\text { C. Bili. } \\
\text { (mg/dL) }\end{array}$ & Median - IQR & \multicolumn{2}{|c|}{$0.84(0.46-1.03)$} & \multicolumn{2}{|c|}{$0.14(0.08-0.16)$} & \multicolumn{2}{|c|}{$0.13(0.1-0.16)$} & $<0.001$ \\
\hline PT (sec) & Mean \pm SD & 16.8 & \pm 1.2 & 12.4 & \pm 0.3 & 12.1 & \pm 0.2 & $<0.001$ \\
\hline INR & Mean \pm SD & 1.7 & \pm 0.2 & 1.0 & \pm 0.0 & 1.0 & \pm 0.0 & $<0.001$ \\
\hline TLC $\left(\times 10^{\times} 3 /\right.$ ul $)$ & Mean \pm SD & 4.7 & \pm 1.2 & 6.5 & \pm 1.5 & 7.2 & \pm 1.7 & $<0.001$ \\
\hline $\begin{array}{c}\text { PLTs }\left(\mathbf{x 1 0}{ }^{x}\right. \\
\text { 3/ul) }\end{array}$ & Mean \pm SD & \multicolumn{2}{|c|}{$\begin{array}{c}117.4(93.3- \\
134)\end{array}$} & \multicolumn{2}{|c|}{$\begin{array}{c}184.8(165.3- \\
192.5)\end{array}$} & \multicolumn{2}{|c|}{$\begin{array}{c}287.8(206.8- \\
365)\end{array}$} & $<0.001$ \\
\hline Hb (g/dl) & Mean \pm SD & 9.7 & \pm 0.8 & 12.0 & \pm 1.3 & 13.1 & \pm 1.0 & $<0.001$ \\
\hline \multirow{2}{*}{ HCV Ab } & Negative & 4 & $13.3 \%$ & 1 & $3.3 \%$ & 20 & $100 \%$ & \multirow{2}{*}{$<0.001$} \\
\hline & Positive & 26 & $86.7 \%$ & 29 & $96.7 \%$ & 0 & $0 \%$ & \\
\hline \multirow{2}{*}{ HBs Ag } & Negative & 26 & $86.7 \%$ & 28 & $93.3 \%$ & 20 & $100 \%$ & \multirow{2}{*}{0.210} \\
\hline & Positive & 4 & $13.3 \%$ & 2 & $6.7 \%$ & 0 & $0 \%$ & \\
\hline $\operatorname{AFP}(\mathbf{I U} / \mathbf{m l})$ & Mean \pm SD & $31.9(2$ & $-11.1)$ & $2.66(1$ & $7-3.4)$ & $2.6(1$. & $-3.35)$ & $<0.001$ \\
\hline $\begin{array}{c}\text { Cholinesterase } \\
(\mathbf{U} / \mathbf{L})\end{array}$ & Mean \pm SD & 2036.0 & \pm 342.0 & 3643.3 & \pm 400.2 & 7507.2 & \pm 1249.1 & $<0.001$ \\
\hline
\end{tabular}




\section{DISCUSSION}

This study showed that Serum Cholinesterase level markedly decreased in patients with liver cirrhosis followed by patients with chronic hepatitis when compared with controls. The difference in the mean was highly statistically significant.

The results of this study were matched with that of Chowdhry (2014) who found that serum cholinesterase levels were found to be significantly decreased in majority of cases of liver disease. Mean serum cholinesterase level was very much lowered in cirrhosis patients as compared to other liver diseases.

Also, this study was consistent with the study done by Abbas and Abbas (2017) who found that mean serum cholinesterase decreased with reduced hepatic reserves. Cholinesterase levels predict survival in patients with parenchymal cirrhosis, distinguish between liver disease and nonliver disease aberration in liver function tests and differentiate cirrhosis from non-cirrhosis.

However, Dhungana (2014) found that butyrylcholinesterase (BChE) level markedly decreased in carcinoma of liver followed by cirrhosis of liver, infective hepatitis, obstructive jaundice when compared with controls. The difference in the mean was statistically significant. Regarding liver diseases, a decreased $\mathrm{BChE}$ activity reflects hepatocellular impairment; similarly, recovery was evidenced by a gradual increase of BChE levels.

However, Gokani et al. (2014) found that, the difference between the mean serum cholinesterase activity of liver diseases and control group was statistically significant with $90 \%$ sensitivity and $100 \%$ specificity, suggesting that reduced serum cholinesterase activity strongly indicate liver dysfunctions. Morever,

Ramachandran et al. (2015) found that median serum $\mathrm{ChE}$ in cirrhotics was $1590 \mathrm{IU} / \mathrm{L}$ compared to controls 7886 IU/L, p<0.001. Furthermore, Meng et al. (2013) showed that the level of cholinesterase is closely correlated with the damage severity of liver cells and may respond to the liver reserve function of cirrhotic patients.

CONCLUSION: There is a strong relationship between lower level of serum cholinesterase in patients with more advanced disease, indicating that reduced serum cholinesterase level is most likely the result of reduced of synthesis from hepatocytes. Cholinesterase can be used as a routine diagnostic test besides other liver function tests for investigation of liver disorders and a prognostic parameter in patients with liver cirrhosis.

\section{ACKNOWLEDGEMENT}

We would like to thank the Clinical Pathology Department and Internal Medicine Department of Al-Azhar Faculty of Medicine. We are also indebted to all the patients and our colleagues for their co-operation in this research.

\section{REFERENCES}

1. Amin MA, El-Shahat M E, ElGarem N, Soliman A and Obaia E (2017):

Assessment of serum level cholinesterase as a biomarker of liver cirrhosis in Egyptian cirrhotic patients. Gastroenterology Insights, 8(1): 15.

2. Chowdhry, V. (2014): Serum cholinesterase as important diagnostic marker to distinguish between liver diseases and non liver diseases. Journal of Evolution of Medical and Dental Sciences, 3(19): 5141-5157.

3. Chowdhry, V. and Kaushik, G. (2017): Estimation of 5' Nucleotidase and Serum Cholinesterase as Diagnostic Marker to Distinguish Between 
Various Liver Diseases and Non Liver Diseases. SSRG International Journal of Medical Science, 4(8): 3-6.

4. Dhungana, A., Sinha, J. N., Sapkota, S. and Athokpam, R. S. (2014): Pseudocholinesterase as a prognostic marker for liver disorder. Journal of Kathmandu Medical College, 3(4): 131-135.

5. Fonseca, L. A., Orozco, A. M., Souto, P. C., Dornelas, L. R., Girardi, F. M., Ermita, P. A. and Fagundes, V. (2020): Plasma cholinesterase activity as an environmental impact biomarker in juvenile green turtles (Chelonia mydas). Pesquisa Veterinária Brasileira, 40(1): 72-76.

6. Gokani, R. S., Jadav, P., Shaikh, N., Shah, R., Chhatriwala, M., and Patel, B. (2014): Serum cholinesterase as diagnostic marker of liver disease. International Journal of Biomedical and Advance Research, 5(9): 439-442.

7. Gülçin, İ., Scozzafava, A., Supuran, C. T., Koksal, Z., Turkan, F., Çetinkaya, S. and Alwasel, S. H. (2016): Rosmarinic acid inhibits some metabolic enzymes including glutathione Stransferase, lactoperoxidase, acetylcholinesterase,

butyrylcholinesterase and carbonic anhydrase isoenzymes. Journal of Enzyme Inhibition and Medicinal Chemistry, 31(6): 1698-1702.

8. Kumar, T. A., and Keerthana, B. L. (2016): Serum cholinesterase as biomarker in liver disorders. International Journal of Applied Research, 2(7): 563-565.

9. Meng, F., Yin, X., Ma, X., Guo, X. D., Jin, B. and Li, H. (2013): Assessment of the value of serum cholinesterase as a liver function test for cirrhotic patients. Biomedical Reports, 1(2): 265268.

10.Ramachandran, J., Sajith, K. G., Priya, S., Dutta, A. K. and Balasubramanian, K. A. (2015): Serum cholinesterase is an excellent biomarker of liver cirrhosis. Tropical Gastroenterology, 35(1): 15-20.

11.Roshankumar, J., Gondhali, M.P. and Mahajan, S. N. (2019): Study of assessment of level of serum cholinesterase in patients with liver diseases. Indian Journal of Basic and Applied Medical Research, 9(1):460-465. 
12.

\section{تقييم مستوى الكولين استراز فى المصل كدلالة تشخيصية

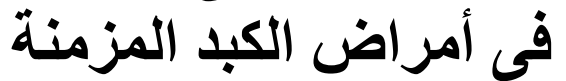

زايد سعيد يوسف حسن * ـ أحمد محمد عبدالرحمن طاحون*- مجدى عبدالكريم الدهثان**ـ أحمد عبدالحميد أبوزيد *

$$
\text { قسمى البانولوجيا الاكلينيكية *و الباطنة العامة **ــ كلية طب الأزهر }
$$

خلفية البحث: يعتبر الكبد هو المصدر الرئيسي لتصنيع الكولين استراز، لذلك هناك ارتباط بين مستوى الكولين

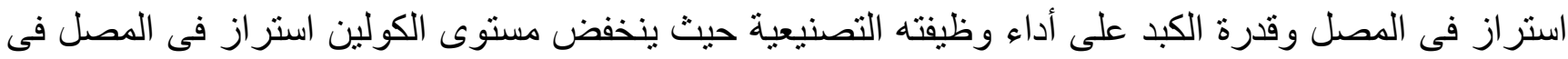
المرضى الذين يعانون من أمراض الكبد المزمنة، كما ان درجة إنخفاض مستوى الكولين استراز فى المصل دئل تتناسب طرديا مع درجة الضرر الذى لحق بالكبد.

الهُف من البحث: تقييم مستوى الكولين استر از فى المصل كدلالة تشخيصية فى أمر اض الكبد المزمنة.

المرضى وطرق البحث: تم أخذ عينات الدم من ستين مريض بأمر اض الكبد المزمنة المحجوزين بقسم الباطنة

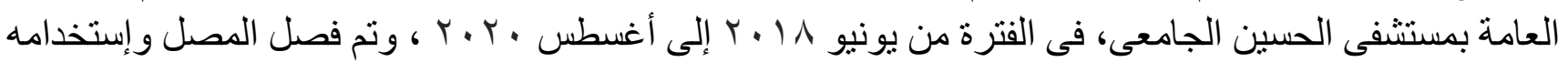

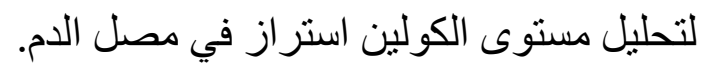
النتائج: وجد إختلاف ذو فيمة إحصائية بين المجموعات فيما يخص الكولين استرازئ فئ وكانت النتائج طبيعية للمجمو عة الضابطة أما المرضى فكان لديهم إنخفاض في مستوى الكولين استراز الاستتتاج: يعتبر قياس مستوى الكولين استراز فى المصل فى أمر اض الكبد المزمنة علامة تشخيصية و إنذارية أفضل من اختبار ات وظائف الكبد التقليدية التي نرتفع في أمر اض أخين أخرى. 